\title{
Security Effect on B2B and B2C Operations using 3G M- Commerce
}

\author{
Avdhesh Gupta \\ College of Engineering Roorkee, Roorkee
}

\author{
Pankaj Madan \\ Associate Professor, GKV, Haridwar
}

\begin{abstract}
The full scope of how mobile technologies will affect individuals' lives in the areas of business, education and other sectors has yet to be appreciated. Innovative mobile technologies are causing disruptive, tectonic changes that will shape inalterably the way the next generation will live, work, play and interact with the rest of the world. Indian business leaders, government, policy makers, leading academics and other experts are required to discuss government and business approaches to mobile commerce, mobile banking, mobile governance and security related issues in M-Commerce that will have a positive effect on India's economic and social development. This paper shows the influences of security on B2B and B2C operations of $3 \mathrm{G}$ based M-Commerce.
\end{abstract}

\section{Keywords}

third generation, m-commerce, security, B2B, B2C.

\section{INTRODUCTION}

E-Commerce, or the buying and selling of goods and services on the Internet, has become a part of daily life for many people. As the Internet expands to every corner of the globe, it is becoming easier and easier to access it from a wide variety of devices [1]. E-Commerce over mobile devices has now been termed Mobile-Commerce (M-Commerce)[2]. The MCommerce by definition is the E-Commerce that is implemented using wireless solutions such as cell phones, pocket PC's, and PDAs. It allows a user to purchase goods and services on the move, anytime, and anywhere. M-Commerce applications and the current $3-\mathrm{G}$ have been finding it hard to be widely used in India. Mobile commerce is a natural result of combining two strongly emerging trends: electronic commerce and pervasive computing. M-Commerce represents another wave of the e-commerce invasion i.e. changing the nature of business in the 21st century [3]

The evolution of mobile network technology can be divided into four generations: 1-G (first generation), 2-G, 2.5-G, and 3-G. Some of the standards for each generation are [4] [5]

- 1-G: Advance Mobile Phone System (AMPS)

- 2-G: Global System for Mobile Communication (GSM), Code Division Multiple Access (CDMA), High Speed Circuit Switched Data Technology (HSCSD)

- 2.5-G: General Packet Radio System (GPRS), Enhanced Data Rate for GSM Evolution (EDGE)

- 3-G: Universal Mobile Telephone Standard (UMTS).
Table 1. Technology and features of various generations

\begin{tabular}{|c|c|c|c|}
\hline Generations & Technology & \begin{tabular}{|c|} 
Bandwidth \\
(Kbps)
\end{tabular} & Features \\
\hline $\begin{array}{l}\text { First } \\
\text { Generation } \\
\text { Mobile (1-G) }\end{array}$ & $\begin{array}{l}\text { Advanced Mobile } \\
\text { Phone System } \\
\text { (AMPS) }\end{array}$ & 9.6 & \begin{tabular}{|} 
Analog voice \\
service \\
No data \\
capabilities \\
\end{tabular} \\
\hline $\begin{array}{l}\text { Second } \\
\text { Generation } \\
\text { Mobile (2-G) }\end{array}$ & $\begin{array}{c}\text { GSM (Global } \\
\text { System for Mobile } \\
\text { Communications) } \\
\text { CDMA (Code } \\
\text { Division Multiple } \\
\text { Access) }\end{array}$ & $9.6-14.4$ & \begin{tabular}{|c|} 
Digital voice \\
and Data \\
services \\
Advance \\
messaging \\
Global \\
Roaming \\
Circuit \\
Switched Data \\
\end{tabular} \\
\hline \begin{tabular}{|l|}
2.5 Generation \\
Mobile $(2.5-G)$
\end{tabular} & $\begin{array}{l}\text { HSCSD (High } \\
\text { Speed Circuit } \\
\text { Switched Data) } \\
\text { GPRS (General } \\
\text { Packet Radio } \\
\text { Services) } \\
\text { EGDE (Enhanced } \\
\text { Data Rates for } \\
\text { Global Evolution) }\end{array}$ & $\begin{array}{l}9.6-57.6 \\
9.6-115 \\
64-384\end{array}$ & $\mid \begin{array}{c}\text { Extension of } \\
\text { GSM } \\
\text { Higher Data } \\
\text { speeds } \\
\text { Packet } \\
\text { Switched Data }\end{array}$ \\
\hline $\begin{array}{l}\text { Third } \\
\text { Generation } \\
\text { Mobile (3-G) }\end{array}$ & \begin{tabular}{|c|} 
IMT-2000 \\
(International \\
Mobile \\
Telecommunications \\
2000) \\
UMTS (Universal \\
Mobile \\
Telecommunications \\
Systems) \\
\end{tabular} & $64-2.048$ & $\begin{array}{l}\text { Always on } \\
\text { IP enabled } \\
\text { Very High } \\
\text { speed data } \\
\text { services }\end{array}$ \\
\hline
\end{tabular}

The third generation mobile networks are based on $2-G$ and 2.5-G networks and have some enhanced features. The underlying technology is same as the previous technology that enables the user to be connected without any interruptions and delays with high efficiency usage of networks. All it matters is to put a new layer on it and to provide the latest and future perspective services. According to a research in Lulea University of Technology the technology and features associated with $3-\mathrm{G}$ are illustrated in the table 1 .

\section{M-COMMERCE APPLICATION FOR B2B AND B2C OPERATIONS}

In a competitive marketplace, the need is to understanding how evolution of 3-G service affects the previous technologies. Financial transaction based organizations have moved from product centric to customer centric position. In this way, companies seek more competitive advantages in building good reputation for superior performance like secure 
financial transaction, on time delivery, accurate information, better-trained personnel and quicker resolution of complaints. The following table shows the B2B and B2C Operations for M-Commerce Applications [3] [6] [7]:

Table 2. B2B and B2C Operations for M-Commerce applications

\begin{tabular}{|c|c|}
\hline $\begin{array}{l}\text { B2B and B2C } \\
\text { Operations }\end{array}$ & M-Commerce Applications \\
\hline $\begin{array}{l}\text { Mobile Financial } \\
\text { Applications (B2C, } \\
\text { B2B) }\end{array}$ & $\begin{array}{l}\text { Banking, brokerage, fund transfer, } \\
\text { payments for mobile users }\end{array}$ \\
\hline $\begin{array}{l}\text { Mobile Advertising } \\
\text { (B2C) }\end{array}$ & $\begin{array}{c}\text { Sending user specific and location } \\
\text { sensitive advertisements }\end{array}$ \\
\hline $\begin{array}{l}\text { Mobile Inventory } \\
\text { Management (B2C, } \\
\text { B2B) }\end{array}$ & $\begin{array}{l}\text { Location tracking of goods, boxes and } \\
\text { People }\end{array}$ \\
\hline $\begin{array}{c}\text { Wireless Data } \\
\text { Centre (B2C, B2B) }\end{array}$ & Information downloaded by mobile users \\
\hline \begin{tabular}{|c|} 
Mobile \\
Entertainment (B2C) \\
\end{tabular} & $\begin{array}{l}\text { Video on demand, online TV, Online } \\
\text { gaming etc. }\end{array}$ \\
\hline \begin{tabular}{|c|} 
Mobile Booking and \\
Ticketing (B2C, \\
B2B) \\
\end{tabular} & $\begin{array}{l}\text { Services allowing customers to book, } \\
\text { tickets for travel, hotel and events }\end{array}$ \\
\hline $\begin{array}{l}\text { Mobile Marketing } \\
\text { Research (B2C) }\end{array}$ & $\begin{array}{l}\text { Obtaining instant feedback from } \\
\text { customers }\end{array}$ \\
\hline $\begin{array}{c}\text { Mobile CRM, } \\
\text { Customer Support } \\
\text { (B2C, B2B) } \\
\end{array}$ & $\begin{array}{l}\text { Customer acquisition and retention by } \\
\text { providing truly personalized content }\end{array}$ \\
\hline $\begin{array}{l}\text { Mobile Distance } \\
\text { Education } \\
\text { (B2C, B2B) }\end{array}$ & $\begin{array}{l}\text { Taking classes, training courses using } \\
\text { streaming video and audio }\end{array}$ \\
\hline $\begin{array}{l}\text { Wireless Business } \\
\text { Re-engineering } \\
\text { (B2C, B2B) }\end{array}$ & $\begin{array}{l}\text { Information up/downloading by mobile } \\
\text { users (e.g. adjusters in an insurance } \\
\text { company. }\end{array}$ \\
\hline
\end{tabular}

\section{STATEMENT OF PROBLEM}

Analysis of impact of security challenges, security risks, and security implementations within 3-G M-Commerce in 3-G MCommerce are the main issues in this research. In today's ECommerce world, the security is the major issues that need to be constantly monitored and improved. For the extensive use of 3-G enabled M-Commerce, it is necessary to see the impact on businesses and their customers. By expanding ECommerce to mobile devices, it is also necessary to ensure that these devices are protected against security threats. MCommerce faces the same security threats that E-Commerce faces plus many others due to the mobile nature of the products [8].

Why the users are not using m-commerce applications? Even B2B and B2C operations are available for M-Commerce applications; the users do not show much attention towards the using m-commerce applications. Even security features have been improved, $3 \mathrm{G}$ (faster internet service on mobiles) has been started, but the number of users is slowly increased [9]. This research shows how the security issues influencing the behavior towards using m-commerce applications.

According to James Messham, fraudsters and hackers will actively target all M-Commerce services, service providers and the underlying infrastructure [10]. An article on "Security in M-Commerce" state that the M-Commerce industry is still in a developing phase. The protocols used in M-Commerce are inherited from E-Commerce [11]. According to Mike Fuller, many security challenges and weaknesses exist within M-Commerce systems. In order to expand the usage of M-
Commerce, the manufacturers, the developers, and the wireless carriers need to gain the consumer trust by implementing the security features into their devices [12]. MCommerce users need some security aspects like Confidentiality, Integrity, non-repudiation, Authentication and Authorization [13][14][15]. Sudhir Dixit et al. said that the third generation networks and services present opportunities to offer multimedia applications and services that meet endto-end quality of service requirements [16].

\section{OBJECTIVES AND HYPOTHESIS}

The main objectives are to examine the impact of security on B2B and B2C operations using 3-G M-Commerce applications and to examine the impact of quality of services on B2B and B2C operations using 3-G M-Commerce applications.

H01: There is no significant difference in the perception of B2B and B2C operators about security in 3G M-Commerce across different demographic characteristics.

H02: There is no significant difference between security issues of $2 \mathrm{G}$ and $3 \mathrm{G}$ networks perceived by $\mathrm{B} 2 \mathrm{~B}$ and $\mathrm{B} 2 \mathrm{C}$ operators.

H03: The user experience does not vary according to various security issues in $3 \mathrm{G}$ based M-Commerce Applications.

H04: Change in 3G Network security issues do not influence the intention to participate in M-Commerce operations.

\section{RESEARCH METHODOLOGY}

The research has been carried out through two key modules: primary research and extensive desk research. The Secondary research has involved an in-depth survey of various literature sources like journals, newspapers, magazines, etc., and primary data collection was done through structured questionnaire and interviews across a cross-section of stakeholders. Extensive desk research has been done to build an in-depth understanding of the security and quality in 3-G M-Commerce applications for B2B and B2C operations. Information from the various published resources such as Journals, Newspapers, Magazines, research papers, etc. and other research bodies has also used to validate the data. It is made with the consideration of the purpose, that is, to gain a better understanding of the dimension that affect the customer, the business perceived M-Commerce security for B2B and B2C operations, the 360-degree stakeholders' survey was done. Further, we did investigation of the customers from various sectors like banks, on line shopping and other B2B operators in northern India.

The primary data has been collected during mid 2011. Also the data was collected through online form submission using 'Gmail' online services. The method creates online form and the data is automatically saved in ms-excel online. The questionnaire was sent to the M-Commerce users and the users are required to fill it online. Snowball sampling approach has been used to find out the real users of $\mathrm{m}$ commerce, since usage of $\mathrm{m}$-commerce is still in the nascent stage in India. The questionnaire has been filled by the users, who are involved in $\mathrm{m}$-commerce transaction or have shifted from manual and e-commerce activities to m-commerce activities. However, deliberate effort has been made to bring randomness in the sample chosen by selecting the respondents based on random sampling from the list of $\mathrm{m}$-commerce users made with the help of snowball sampling []17[18]. The data of online form submission is saved in ms-excel form. Data was collected, coded and entered into SPSS 12.0 before 
processing the same for analysis. Statistical tools used to analyze the data as per the objectives included Descriptive Statistics (such as frequencies, Percentages, Arithmetic Averages, Standard Deviations), reliability and validity, Ttest, chi-square test.

\section{RESULTS INTERPRETATION}

The data collected through 'Gmail' service and implemented into SPSS. Some methods applied on data to get the results. Following are the results for various hypotheses:

H01: There is no significant difference in the perception of B2B and B2C operators for 3G M-Commerce Applications across different demographic characteristics.

Table 3. Descriptive statistics for relationship between B2B and B2C

\begin{tabular}{|c|c|c|c|c|c|c|c|c|}
\hline \multirow[b]{2}{*}{ Factors } & \multicolumn{4}{|c|}{ B2C } & \multicolumn{4}{|c|}{ B2B } \\
\hline & $\mathbf{N}$ & $\begin{array}{c}\text { Mea } \\
\text { n }\end{array}$ & S.D. & $\begin{array}{l}\text { Std. } \\
\text { Error } \\
\text { Mean }\end{array}$ & $\mathbf{N}$ & Mean & .D. & $\begin{array}{c}\text { Std. } \\
\text { Erro } \\
\text { r } \\
\text { Mea } \\
\text { n }\end{array}$ \\
\hline $\begin{array}{l}\text { Age Wise } \\
\text { Group }\end{array}$ & 201 & 2.76 & 1.055 & .074 & 104 & 3.54 & 1.314 & .129 \\
\hline City Wise & 201 & 1.10 & .361 & .025 & 104 & 1.02 & .138 & .014 \\
\hline Gender & 201 & 1.37 & .485 & .034 & 104 & .38 & .486 & .048 \\
\hline $\begin{array}{c}\text { Education } \\
\text { Qualificati } \\
\text { on }\end{array}$ & 201 & 2.77 & .421 & .030 & 104 & .75 & .435 & .043 \\
\hline $\begin{array}{l}\text { Marital } \\
\text { Status }\end{array}$ & 201 & 1.25 & .436 & .031 & 104 & 1.16 & .372 & .036 \\
\hline Occupation & 201 & 2.06 & .341 & .024 & 104 & 2.35 & .517 & .051 \\
\hline Income & 201 & 3.58 & 1.306 & .092 & 104 & 4.17 & 1.210 & .119 \\
\hline $\begin{array}{l}\text { Mobile } \\
\text { Device }\end{array}$ & 201 & 1.68 & 1.009 & .071 & 104 & 1.51 & .955 & .094 \\
\hline $\begin{array}{c}\text { Brand } \\
\text { Name of } \\
\text { Mobile }\end{array}$ & 201 & 2.26 & 1.773 & .125 & 104 & 1.69 & 1.462 & .143 \\
\hline Cost & 01 & 2.37 & .643 & .045 & 104 & 2.47 & .607 & .059 \\
\hline $\begin{array}{c}\text { 3G Service } \\
\text { Provider }\end{array}$ & 201 & 2.10 & 1.513 & .107 & 104 & 1.98 & 1.157 & .113 \\
\hline
\end{tabular}

Table 4. Chi-Square Test to identify the relationship between B2B and B2C

\begin{tabular}{|l|r|r|r|}
\hline \multicolumn{1}{|c|}{ Factors } & \multicolumn{1}{|c|}{ Value } & df & \multicolumn{1}{c|}{$\begin{array}{c}\text { Asymp. Sig. } \\
\text { (2-sided) }\end{array}$} \\
\hline $\begin{array}{l}\text { Pearson Chi-Square for } \\
\text { AGE }\end{array}$ & $.014(\mathrm{~b})$ & 1 & .907 \\
\hline $\begin{array}{l}\text { Pearson Chi-Square for } \\
\text { QUALIFICATION }\end{array}$ & $.170(\mathrm{~b})$ & 1 & .680 \\
\hline $\begin{array}{l}\text { Pearson Chi-Square for } \\
\text { MARITAL STATUS }\end{array}$ & $45.251(\mathrm{a})$ & 3 & .000 \\
\hline $\begin{array}{l}\text { Pearson Chi-Square for } \\
\text { INCOME GROUP }\end{array}$ & $31.066(\mathrm{a})$ & 4 & .000 \\
\hline $\begin{array}{l}\text { Pearson Chi-Square for } \\
\text { OCUUPATION }\end{array}$ & $45.251(\mathrm{a})$ & 3 & .000 \\
\hline $\begin{array}{l}\text { Pearson Chi-Square for } \\
\text { 3G NETWORK }\end{array}$ & $28.014(\mathrm{a})$ & 4 & .000 \\
\hline $\begin{array}{l}\text { Pearson Chi-Square for } \\
\text { CITY WISE }\end{array}$ & $4.781(\mathrm{a})$ & 2 & .092 \\
\hline
\end{tabular}

Here the relationship identification between $\mathrm{B} 2 \mathrm{~B}$ and $\mathrm{B} 2 \mathrm{C}$, so there is relationship between $\mathrm{B} 2 \mathrm{~B}$ and $\mathrm{B} 2 \mathrm{C}$ according to marital status, income group, occupation, network, and the age of person, while there is no relationship between $\mathrm{B} 2 \mathrm{~B}$ and $\mathrm{B} 2 \mathrm{C}$ according to qualification, gender and city. So for the use of $\mathrm{B} 2 \mathrm{~B}$ or $\mathrm{B} 2 \mathrm{C}$ operation there is no hard and fast rule to do these operations by a selected group. Basically highly qualified, male, unmarried, high income group and middle aged persons are the main users of B2B and B2C operations. So this research shows that for the identification of impact of security and quality in $3 \mathrm{G} \mathrm{m}$-commerce applications on $\mathrm{B} 2 \mathrm{~B}$ and B2C operations, both operations can be taken collectively. So the hypothesis $\mathrm{H} 01$ is agreed that there is no significance difference in the perception of $\mathrm{B} 2 \mathrm{~B}$ and $\mathrm{B} 2 \mathrm{C}$ operations for $3 \mathrm{G} \mathrm{m}$-commerce applications across different characteristics.

H02: There is no significant difference between security issues of $2 \mathrm{G}$ and $3 \mathrm{G}$ networks perceived by $\mathrm{B} 2 \mathrm{~B}$ and $\mathrm{B} 2 \mathrm{C}$ operators.

Table 5. One sample test for comparison of security attributes between $3 \mathrm{G}$ network and $2 \mathrm{G}$ or $2.5 \mathrm{G}$ network

\begin{tabular}{|c|c|c|c|c|c|c|}
\hline \multirow{3}{*}{ Factors } & \multicolumn{6}{|c|}{ Test Value $=3$} \\
\hline & \multirow{2}{*}{$\mathrm{t}$} & \multirow[t]{2}{*}{$\mathrm{df}$} & \multirow{2}{*}{$\begin{array}{l}\text { Sig. (2- } \\
\text { tailed) }\end{array}$} & \multirow{2}{*}{$\begin{array}{c}\text { Mean } \\
\text { Difference }\end{array}$} & \multicolumn{2}{|c|}{$\begin{array}{l}95 \% \text { Confidence } \\
\text { Interval of the } \mathrm{df}\end{array}$} \\
\hline & & & & & Lower & Upper \\
\hline \begin{tabular}{|l|} 
Trust on \\
Network
\end{tabular} & .490 & 304 & .625 & .030 & -.09 & .15 \\
\hline \begin{tabular}{|l|} 
Secure \\
$3 \mathrm{G}$ \\
Accessib \\
ility \\
\end{tabular} & .918 & 304 & .360 & .056 & -.06 & .18 \\
\hline $\begin{array}{l}\text { Security } \\
\text { in } 3 G \text { as } \\
\text { in } 2 G\end{array}$ & 6.99 & 304 & .000 & .357 & .26 & .46 \\
\hline \begin{tabular}{|l|} 
Overall \\
Security
\end{tabular} & 7.40 & 304 & .000 & .403 & .30 & .51 \\
\hline
\end{tabular}

This table displays the number of cases, mean value, standard deviation, and standard error for the test variable(s). Since the One-Sample $\mathrm{T}$ Test procedure compares the mean to a specified value, it is useful to know what the mean value is. The test observed that

- a significance value of 0.625 in case of trust on 3G networks, indicates that there is no significant difference between security issues of $2 \mathrm{G}$ and $3 \mathrm{G}$ networks perceived by $\mathrm{B} 2 \mathrm{~B}$ and $\mathrm{B} 2 \mathrm{C}$ operators.

- a significance value of 0.360 in case of secure 3G accessibility, indicates that there is no significant difference between security issues of $2 \mathrm{G}$ and $3 \mathrm{G}$ networks perceived by B2B and B2C operators.

- a significance value of 0.000 in case of more security in $3 \mathrm{G}$ network as compared to $2 \mathrm{G}$ network, indicates a significant difference between security issues of $2 \mathrm{G}$ and $3 \mathrm{G}$ networks perceived by $\mathrm{B} 2 \mathrm{~B}$ and $\mathrm{B} 2 \mathrm{C}$ operators.

- a significance value of 0.000 in case of speed, indicates a significant difference between security issues of $2 \mathrm{G}$ and $3 \mathrm{G}$ networks perceived by $\mathrm{B} 2 \mathrm{~B}$ and $\mathrm{B} 2 \mathrm{C}$ operators. 
H04: The user experience does not vary according to various quality and security issues in $3 \mathrm{G}$ based M-Commerce Applications.

Table 6. One sample test for user experience for attributes

\begin{tabular}{|c|c|c|c|c|c|c|}
\hline \multirow{3}{*}{ Factors } & \multicolumn{6}{|c|}{ Test Value $=3$} \\
\hline & \multirow[t]{2}{*}{ ( } & \multirow[t]{2}{*}{ df } & \multirow{2}{*}{$\begin{array}{c}\text { Sig. } \\
(2- \\
\text { tailed })\end{array}$} & \multirow[t]{2}{*}{$\begin{array}{l}\text { Mean } \\
\text { Diff. }\end{array}$} & \multicolumn{2}{|c|}{$\begin{array}{c}95 \% \\
\text { Confidence } \\
\text { Interval of } \\
\text { df }\end{array}$} \\
\hline & & & & & $\begin{array}{l}\text { Low } \\
\text { er }\end{array}$ & Upper \\
\hline Confidentiality & 9.428 & 304 & .000 & .672 & .53 & .81 \\
\hline Authentication & 15.239 & 304 & .000 & .764 & .67 & .86 \\
\hline Integrity & 12.491 & 304 & .000 & .564 & .48 & .65 \\
\hline Network Trust & 8.491 & 304 & .000 & .449 & .35 & .55 \\
\hline Mobile Trust & 4.238 & 304 & .000 & .216 & .12 & .32 \\
\hline \begin{tabular}{|l} 
Protocols \\
Compatibility
\end{tabular} & 6.368 & 304 & .000 & .357 & .25 & .47 \\
\hline \begin{tabular}{|lr} 
Secure & Data \\
Transfer & \\
\end{tabular} & 5.616 & 304 & .000 & .361 & .23 & .49 \\
\hline $\begin{array}{l}\text { Transaction } \\
\text { Speed }\end{array}$ & 10.653 & 304 & .000 & .692 & .56 & .82 \\
\hline $\begin{array}{l}\text { Simple Format } \\
\text { for Transaction }\end{array}$ & 11.875 & 304 & .000 & .784 & .65 & .91 \\
\hline $\begin{array}{l}\text { Redirection and } \\
\text { use of links }\end{array}$ & 1.220 & 304 & .223 & .062 & -.04 & .16 \\
\hline
\end{tabular}

This one table statistics displays the number of cases, mean value, standard deviation, and standard error for the test variable(s). Since the One-Sample T Test procedure compares the mean to a specified value, it is useful to know what the mean value is. The test observed:

- a significance value of 0.000 , indicates that there is significant difference i.e. the user experience vary according to various security issues in $3 \mathrm{G}$ based $\mathrm{M}$ Commerce Applications.

- a significance value of 0.223 in case of Redirection and use of links, indicates that there is no significant difference or the user experience does not vary in 3G based M-Commerce Applications.

H05: Change in 3G Network security issues do not influence the intention to participate in M-Commerce operations.

Table 7. chi square statistics for availability of government regulation

\begin{tabular}{|c|c|c|c|}
\hline & Observed N & Expected N & Residual \\
\hline YES & 183 & 152.5 & 30.5 \\
\hline NO & 122 & 152.5 & -30.5 \\
\hline Total & 305 & & \\
\hline
\end{tabular}

Table 8. chi square statistics for trust intention towards using M-Commerce

\begin{tabular}{|c|c|c|c|}
\hline & Observed N & Expected N & Residual \\
\hline YES & 249 & 152.5 & 96.5 \\
\hline NO & 56 & 152.5 & -96.5 \\
\hline Total & 305 & & \\
\hline
\end{tabular}

Table 9. chi square statistics for problem faced in MCommerce

\begin{tabular}{|c|c|c|c|}
\hline & Observed N & Expected N & Residual \\
\hline YES & 166 & 152.5 & 13.5 \\
\hline NO & 139 & 152.5 & -13.5 \\
\hline Total & 305 & & \\
\hline
\end{tabular}

Table 10. chi square statistics for knowledge increase by using M-Commerce

\begin{tabular}{|c|c|c|c|}
\hline & Observed N & Expected N & Residual \\
\hline YES & 274 & 152.5 & 121.5 \\
\hline NO & 31 & 152.5 & -121.5 \\
\hline Total & 305 & & \\
\hline
\end{tabular}

In this hypothesis test, the observed number of different security attributes shows the behavioural intention with the M-Commerce activities. The government rules and regulation for security purpose is available. The transaction is completely secure, and all M-Commerce website follows these rules and regulations. Trust intention towards use of MCommerce is very fine. Because all M-Commerce and ecommerce websites follow government rules and regulation and thus it create trust among users. 249 out of 305 users respond that trust intention creates more users to do MCommerce transaction. In addition, knowledge of security in $\mathrm{M}$-Commerce increases the user of $\mathrm{M}$-Commerce. There are so many users, who faced problems in M-Commerce transaction.

Table 11. chi square test statistics for user intention according to security attributes

\begin{tabular}{|c|c|c|c|c|}
\hline & $\begin{array}{c}\text { Availabilit } \\
\text { y of Govt. } \\
\text { Regulatio } \\
\mathrm{n}\end{array}$ & $\begin{array}{c}\text { Trust } \\
\text { towards } \\
\text { using M- } \\
\text { Comm. }\end{array}$ & $\begin{array}{c}\text { Faced } \\
\text { Proble } \\
\text { m in M- } \\
\text { Comm. }\end{array}$ & $\begin{array}{c}\text { Knowled } \\
\text { ge } \\
\text { Increase } \\
\text { by using } \\
\text { M- } \\
\text { Comm. }\end{array}$ \\
\hline $\begin{array}{c}\text { Chi- } \\
\text { Square(a) }\end{array}$ & 12.200 & 122.128 & 2.390 & 193.603 \\
\hline df & 1 & 1 & 1 & 1 \\
\hline $\begin{array}{c}\text { Asymp. } \\
\text { Sig. }\end{array}$ & .000 & .000 & .122 & .000 \\
\hline
\end{tabular}

a 0 cells $(.0 \%)$ have expected frequencies less than 5 . The minimum expected cell frequency is 152.5 .

This test indicates that the observed distribution does not conform to the hypothesized distribution. The significance level is less than .05. The distribution of security attributes differs from the distribution hypothesized. Only one factor has mare that 0.5 significance level. Most of the users are facing problems in M-Commerce transaction. The problems arise due to less experience and less awareness of M-Commerce transactions. This creates not to do M-Commerce transaction.

\section{CONCLUSION}

The Indian people does not show much interest in MCommerce activity, because of less trust on mobile devices, less awareness and less trust on networks. Therefore, it is very difficult to collect the data from the actual users. For data collection, I tried to users to do M-Commerce transaction, so that the result can be interpreted in a right way.

The users are afraid to do M-Commerce transaction because of the trust on $3 \mathrm{G}$ wireless network, trust of their mobile devices and the network availability of $3 \mathrm{G}$ networks 
everywhere without interrupting the transaction. Redirection and use of links is not properly handled by the user and user is unable to explore all the links available on web page, because some of the web pages will open in new window, then how to access that new window, or how to reach the previous window (most of the mobile devices are not multitasking). The major problem faced by the user is the network availability of $3 \mathrm{G}$ network.

The impact of security in 3G M-Commerce applications on $\mathrm{B} 2 \mathrm{~B}$ and $\mathrm{B} 2 \mathrm{C}$ operation is not so positive, because the users have not faith on their mobile devices, the $3 \mathrm{G}$ network availability and the trust on $3 \mathrm{G}$ networks.

The user is not much aware about the m-commerce applications, so the policies should be made in this regard to promote and regulate 3-G M-Commerce in India.

If the user is aware about the m-commerce application, then also he/she could not create faith in m-commerce. Also from the side of m-commerce application provider, the security mechanism is adopted. This $3 \mathrm{G}$ service provider, mcommerce application provider and the government should create some regulations in this regard. Then only the users create the faith to do m-commerce transaction.

\section{LIMITATIONS AND FUTURE SCOPE OF THE RESEARCH}

- One of the main limitations is that during the course of research, many new companies have $3 \mathrm{G}$ license and many new users have not been made the part of sample.

- The sample size in this research study is 305. A significantly large sample size may be more representative of population.

- This study focused on Banks, Ticket Booking and Online Shopping operations only. The study is confined to MCommerce applications for B2C and B2B operations in northern region only.

- Only 3-G M-Commerce related security issues would be addressed, while 4-G M-Commerce has been already initiated in developed countries.

\section{REFERENCES}

[1] http://www.indiainfoline.com/cyva/repo/mcom/ch01.htm 1 (Dec. 2011)

[2] Shahidul Islam, 2006 Mobile Commerce, A Master Thesis for Lulea University of Technology
[3] P. Venkataram, 2003 Mobile Commerce - Vision and Challenges, at ITPC, Nepal, IISc Bangalore INDIA

[4] http://www.thesspa.com/sspanews/102010/article2.asp (Oct. 2011)

[5] Aftab and Iqbal, 2006 3-G Mobile Communication Services Perspective, A Master Thesis for Lulea University of Technology

[6] commerce:http://www.smarte-commerce.com/emergingM-Commerce/ (July 2011)

[7] endec:http://www.endeca.com/en/resourcecenter/whitepapers/b2b-ecommerce-trends-2011.html accessed (Feb. 2012)

[8] http://www.india-reports.com/summary/ ecommerce_in_india.aspx (Nov. 2011)

[9] Ghosh, K.A., and Swaminatha, T.M., Software security and privacy risks in mobile ecommerce, Communications of the ACM, Volume 44 (2), Feb 2001, pp 51-57

[10] James Messham, 2000, M-Commerce Security, International Clearing House Ltd.

[11] Scarlet, Knospe 2011, Security in M-Commerce, (Aug. 2011)

[12] Mike Fuller, M-Commerce and Security, A Project http://theory.stanford.edu/ iliano/courses/06S-GMUISA767/project/papers/fuller.pdf (Oct. 2011)

[13] Mynttinen J, 2001 End to End security of mobile data in GSM, Helsinki University of Technology, Helsinki, Finland

[14] Hage D.,2001 Secure E-Commerce: WAP security in MCommerce, University of South Australia

[15] Vyas, A,, O'Grady, P., 2001 Areview of M-Commerce technologies, Internet lab technical report, Unversity of IOWA.

[16] Sudhir Dixit, Yile Guo, and Zoe Antoniou(Feb-2001, Resource Management and Quality of Service in ThirdGeneration Wireless Networks, IEEE Communications Magazine, PP 125-133.

[17] Leo A. Goodman, August 2011 Sociological Methodology, Volume 41, Issue 1, pages 34-353.

[18] Mark S. Handcock, Krista J. Gile Aug 2011 arXiv:1108.0301v1 [stat.AP] 